\title{
IDENTIFYING THE TYPES OF MARKETING AND SALE OF CARPETS AND RUGS OF ILAM PROVINCE ENTREPRENEURS
}

\author{
Maryam Majidi \\ Department of Marketing Management, Ilam Science and Research Branch, Islamic Azad University, \\ Ilam, Iran \\ Mohammad Eidi \\ Department of Marketing Management, Ilam Science and Research Branch, Islamic Azad University, \\ Ilam, Iran
}

\begin{abstract}
The aim of this study is to identify ways of marketing and sales of carpets and rugs entrepreneurs in Ilam province. This research is descriptive-correlation method that has been conducted in field. The target population in this study consisted of scholars, experts, hand-made carpets and rugs, in Ilam province to 120 people. Due to the limited population of the province in the field of hand-made carpets and rugs allcensus, the census is used. The gathered data from two questionnaires with 28 questions is mixed marketing and sales entrepreneurial questionnaire that included questions is 9, was used. Their Cronbach's alpha is 0.76 and 0.78 , respectively. To analyze the data, t-test was used to rank single group and Friedman. Data analysis was performed using software spss22. The results showed that advertising is the key to selling hand-made carpets and rugs. After that, the second is the distribution channel and price and the factors related to the product ranked third and fourth.
\end{abstract}

Keywords: marketing, sales, carpets and rugs

\section{INTRODUCTION}

In fact, progress is a farewell to the past and the past, light the future, the reality is that in the future the past, present and future cannot be absolutely wiped the last of the composition of (Esfandiari, 2008). In any case, the future, present and past, there should be a clear difference, that is, the changes in the elements and structures that nation sees it and obviously developed is based on the time axis. The successful companies have in [global competitiveness in international markets are in search of opportunities to achieve their desired goals and protect their own markets from the position and survival of (Esfandiari et al, 2010). Although the carpet, as the most noble Iranian handicraft is tied with the name of my country and the world known carpet with Iran, one of the most authentic and traditional crafts among the people of Ilam province in recent years has been invented "carpet embossed" the shortcomings of traditional crafts development in the country, is also facing the original art and the new Elamite. Crafts masterpieces of human art in the development of science, culture, economics and community development have an important role and can serve as the cause of the relationship between the United Nations and be based on the principles of cultural communication in the world. In the meantime, Iran Ilam Province, in terms of handicrafts rich and diverse they are trying to achieve through sustainable development but it is clear Achieving this goal requires an understanding of crafts and factors and identifying the types of marketing and sales at building and its diversity as well as its social effects. Tribal life, traditional livestock livelihoods for life, made people in the region of Ilam province has long been closely co-existence with wool and yarn. For this reason, crafts related to these products, especially carpets and rugs in the province's prosperity. In terms of consumption, the bulk of carpets and rugs produced by women is woven and consumer aspects. Carpet leading role, in terms of originality and production, the most important and the most distinctive handicrafts and indigenous people is of Ilam 
province. Due to the creativity of the master weavers in the context Elamite bas-relief products, it has made great progress in the field of products. Generally, hand-made carpets and rugs in Ilam province is of great prosperity, comes. Each year significant quantities of carpets and rugs, hand-made carpets and rugs weaving centers of Ilam province that are part of its production is for domestic consumption and the rest is exported to foreign countries. Scientific research about carpets and rugs in Ilam province is limited. Therefore, research in this field an important step in recognizing, preserving and promoting the artistic heritage. The field research method aimed at identifying ways of marketing and selling hand-made carpets and rugs Ilam province's entrepreneurs. Select the most appropriate approach to domestic and foreign markets, shaping the strategies of a firm's entry into these markets as well. A variety of methods, each with advantages and disadvantages that have production units' carpets and rugs have led to special measures to consider in this regard. Devastating defeat that some production units and carpet products in the domestic and foreign markets have experienced. Researchers Management Sciences and Economics has also sensitive to this issue, so that the interdisciplinary field called "entry method" to check and analysis of this issue has emerged (Chen et al, 2010). Theories input method can be divided into two categories: descriptive and prescriptive. More descriptive theory to describe and analyze the behavior of firms and their different experiences in entering big markets addressed and prescriptive theory is also based on descriptive theory, the decision-making process and the introduction of effective strategies, will help to select the correct input. Now our country is moving towards a knowledge-based economy is of great importance and necessity of this transformation, interaction and exchange of knowledge, technology and products with the world. Knowledge of the mechanisms and methods of entry to world markets for companies and organizations who are on the path of globalization, is a fundamental necessity (Novak, 2010). Globalization as a dominant phenomenon in the global economy in recent years, and especially in the current situation with global embargo on Iranian markets, a significant impact on manufacturing and service organizations will leave strategies. One of these effects, importance and complexity of carpets and rugs Province entry to foreign markets (Webster, 2005). In the past, entering a foreign market through transit and destination market sales happening now numerous ways and mechanisms to enter a market out that selecting input method that effectively among them, can lead to successful market presence. It is important that carpets and rugs two very prominent role of Ilam province in the country where it is considered among the best and quality textures. Therefore, addressing the issues mentioned can be a big step for knitting Elamite have the right to determine what is the working class to be awarded (Ahmad \& Darwish, 2011). The paper attempts, on the basis of theoretical principles combined with the experience gathered from the literature and discuss some of the exporters of carpet and rugs in the province and the country, opens new valves to managers and decision makers, companies and cooperatives influential in global markets. Given that the issues involved can be stated that this study is to identify ways of marketing and selling carpets and rugs of Ilam province's entrepreneurs. So that appropriate strategies can produce carpets and rugs with the terms of the province surrounding the production was re-opened.

\section{METHODOLOGY}

This research is descriptive-correlation method that has been conducted in field. The target population in this study consisted of scholars, experts, hand-made carpets and rugs, in Ilam province to 120 people. Due to the limited population of the province in the field of hand-made carpets and rugs all-census, the census is used. The gathered data from two questionnaires with 28 questions is mixed marketing and sales entrepreneurial questionnaire that included questions is 9, was used. Their Cronbach's alpha is 0.76 and 0.78 , respectively. To analyze the data, t-test was used to rank single group and Friedman. Data analysis was performed using software SPSS22.

\section{FINDINGS}

In the descriptive part, the results indicate that the majority of subjects in this study population, 75 patients $(62.5 \%)$ were male. The age of the study population, 66 patients (55.0 percent) were aged 30 to 40 years. According to Kolmogorov-Smirnov test result, all research questions have significantly higher levels of 0.5 . 
Table 1. Results Kolmogorov - Smirnov

\begin{tabular}{|c|c}
\hline Kolmogorov - Smirnov test & sig \\
\hline Quality effect on the sale of carpets and rugs & 0.072 \\
\hline effect of price on the sale of carpets and rugs & 0.068 \\
\hline advertisement of price on the sale of carpets and rugs & 0.087 \\
\hline distribution channel on Carpets and rugs sales & 0.076 \\
\hline
\end{tabular}

According to Kolmogorov-Smirnov test result significantly above the 0.5 level all significant research questions. Therefore, data are normal. So, to test the research questions parametric tests should be used.

Table 2. single-sample t-test results for scale factors related to the product

\begin{tabular}{|c|c|c|c|c|c|c}
\hline \multicolumn{2}{|c|}{$\begin{array}{c}\text { Confidence interval } \\
95 \%\end{array}$} & \multirow{2}{*}{ Sig } & $\mathrm{t}$ & $\begin{array}{c}\text { Standard } \\
\text { deviation }\end{array}$ & mean & $\begin{array}{c}\text { Average one-sample t-test variables } \\
\text { related to the scale factors related to } \\
\text { the product }\end{array}$ \\
\cline { 1 - 5 } $\begin{array}{c}\text { higher } \\
\text { bound }\end{array}$ & $\begin{array}{c}\text { Lower } \\
\text { bound }\end{array}$ & & & & \\
\hline 3.73 & 3.39 & 0.000 & 35.32 & 1.12 & 4.00 & \\
\hline
\end{tabular}

Results in Table 2, according to test results $t=35.32$, are at a significance level (0.05) because the amount $\mathrm{t}$ of 1.96 is the standard level. Thus, $\mathrm{H} 0$ is rejected and the default is $1 \mathrm{H}$ approved.

Table 3. The results of the one-sample t-test for scale price

\begin{tabular}{|c|c|c|c|c|c|c|}
\hline \multicolumn{2}{|c|}{$\begin{array}{c}\text { Confidence } \\
\text { interval \%95 }\end{array}$} & \multirow{2}{*}{ Sig } & $\mathrm{t}$ & $\begin{array}{c}\text { Standard } \\
\text { deviation }\end{array}$ & mean & $\begin{array}{c}\text { Average one-sample t-test } \\
\text { variables related to the scale } \\
\text { factors related to the product }\end{array}$ \\
\cline { 1 - 5 } $\begin{array}{c}\text { Higher } \\
\text { bound }\end{array}$ & $\begin{array}{c}\text { Lower } \\
\text { bound }\end{array}$ & & & & \\
\hline 3.74 & 3.28 & 0.000 & 36.02 & 1.11 & 4.00 & \\
\hline
\end{tabular}

Results in Table 3, according to test results $t=36.02$, are at a significance level $(0.05)$ because the amount $\mathrm{t}$ of 1.96 is the standard level. Thus, $\mathrm{H} 0$ is rejected and the default is $1 \mathrm{H}$ approved.

Table 4. The results of the one-sample t-test for scale advertising

\begin{tabular}{|c|c|c|c|c|c|c|}
\hline \multicolumn{2}{|c|}{$\begin{array}{c}\text { Confidence } \\
\text { interval \%95 }\end{array}$} & Sig & $\mathrm{t}$ & $\begin{array}{c}\text { Standard } \\
\text { deviation }\end{array}$ & mean & $\begin{array}{c}\text { Average one-sample t-test } \\
\text { variables related to the scale of } \\
\text { advertising }\end{array}$ \\
\cline { 1 - 5 } $\begin{array}{c}\text { Higher } \\
\text { bound }\end{array}$ & $\begin{array}{c}\text { Lower } \\
\text { bound }\end{array}$ & & & & \\
\hline 3.74 & 3.28 & 0.000 & 35.41 & 1.11 & 4.00 & \\
\hline
\end{tabular}

Results in Table 4, according to test results $t=35.41$, are at a significance level (0.05) because the amount t of 1.96 is the standard level. Thus, $\mathrm{H} 0$ is rejected and the default is $1 \mathrm{H}$ approved.

Table 5. The results of the one-sample t-test for scale distribution channel 


\begin{tabular}{|c|c|c|c|c|c|c}
\hline \multicolumn{2}{|c|}{$\begin{array}{c}\text { Confidence } \\
\text { interval \%95 }\end{array}$} & Sig & $\mathrm{t}$ & $\begin{array}{c}\text { Standard } \\
\text { deviation }\end{array}$ & mean & $\begin{array}{c}\text { Average one-sample t-test } \\
\text { variables related to the scale of } \\
\text { distribution channels }\end{array}$ \\
\cline { 1 - 5 } $\begin{array}{c}\text { Higher } \\
\text { bound }\end{array}$ & $\begin{array}{c}\text { Lower } \\
\text { bound }\end{array}$ & & & & \\
\hline 3.74 & 3.28 & 0.000 & 35.03 & 1.23 & 4.00 & \\
\hline
\end{tabular}

Results in Table 5, according to test results $t=35.03$, are at a significance level $(0.05)$ because the amount $\mathrm{t}$ of 1.96 is the standard level. Thus, $\mathrm{H} 0$ is rejected and the default is $1 \mathrm{H}$ approved.

Table 6. Ranking the component of marketing methods

\begin{tabular}{c|c|c|c|c}
\hline result & Sig & Degrees of freedom & Chi square & sample \\
\hline Rating is possible. & 0.000 & 3 & 7.819 & 120 \\
\hline
\end{tabular}

According to Table 6, sig amount equal to $000 \ldots$ Is. Since sig is significantly below the surface, therefore, the null hypothesis cannot be confirmed. We can say that the variables have the same rank and can be prioritized. Component priority order shown in the table 7.

Table 7. Friedman test

\begin{tabular}{|c|c|}
\hline variables & Average ratings \\
\hline advertising & 2.68 \\
\hline Distribution channels & 2.56 \\
\hline price & 2.52 \\
\hline product & 2.24 \\
\hline
\end{tabular}

\section{DISCUSSION AND CONCLUSION}

The results show that the question of diversity of products offered (to a variety of products in each serving), size suitable for the product, product color design, product quality as it has been promised, delivered at the right time, designer and texture product, harmony of colors and designs of factors related to quality, the sale of carpets and rugs are handmade. The issues raised by the first question, the $t$ more than the standard level. Therefore, assuming the null hypothesis is rejected and is a confirmed. The assumption is that there is a significant and positive impact the factors related to the product and selling handmade rugs and carpets. So the first question, research, verify, and these findings factors related to the sale of goods Carpets and rugs entrepreneurs) are in parallel (with the findings of Esfahani and Rudabadi (2012) and Akbarzada et al (2011). The decision to set policy questions related to commodity prices, decisions on policy combining elements of marketing, responsible for determining the price of the product, the rules affecting the price (legal policy), covering the cost of production, distribution and sales, awareness of the relationship between commodity prices and demand which, considering the economic conditions and consequences of the implementation of pricing policies, price factors are related to the sale of carpets and rugs handmade.

The issues raised by the second question, the t test is higher than the standard level. Therefore, assuming the null hypothesis is rejected and is a confirmed. There is a significant and positive impact between the price and the sale of carpets and rugs. So, the second question is approved, and the findings (the price 
impact on sales of carpets and rugs entrepreneurs) are in parallel with the findings of Esfahani and Rudabadi (2012) and Akbarzada et al (2011). The results showed that the questions set a clear propaganda purposes, to determine the advertising budget for each of the goods, the role of advertising in influencing the demand for goods, supplying innovative advertising messages over budget, according to the advertising and communication, media selection, chosen by messengers, the decision about the timing of media are among advertising factors on the sale of hand-made carpets and rugs.

The issues raised by the third question, the $t$ more than the standard level. Therefore, the null hypothesis is rejected, and given an approval. There is a significant and positive impact between advertising and sale of carpets and rugs. Therefore, the third research question is approved. These findings (advertising impact on sales of carpets and rugs entrepreneurs) are in parallel with the findings of Esfahani and Rudabadi (2012) and Akbarzada et al (2011).

The results showed that the questions co-founding member distribution channels, functions of distribution channels, choosing distribution channels, determine the number of intermediaries in the distribution channel of distribution, distribution channel strategy in the context of marketing methods designed, strong desire to draw strategies distribution channel are among factors on distribution channel sales of handmade carpets and rugs. The issues raised fourth question, the $t$ more than the standard level. Therefore, assuming the null hypothesis is rejected and is a confirmed. There is a positive and significant impact between distribution and sale of carpets and rugs, hand-made channel. The fourth question is approved study. These findings (carpets and rugs entrepreneurs' sales distribution channel effect) are in parallel with the findings of Esfahani and Rudabadi (2012) and Akbarzada et al (2011). The results showed that advertising is the key to selling hand-made carpets and rugs. Followed by distribution channel is in second place. Then, the price and the factors related to the product ranked third and fourth.

\section{REFERENCES}

Ahmadi, Ali Akbar. Darwish, Hassan. (2012). Entrepreneurship. Payam Noor University Press. Fourth edition.

Akbarzada, Jafar. Ghaffari, Mohammad. Radmehr, Reza. (2011). the study of the Influence of modern principles of marketing in increasing Iran's carpet exports. Third National Conference on Textile and Clothing Engineering, Yazd.

Chen, Su. Me and Lai, Si. Jen. (2010). "Distribution System, Loyalty \& Performance". International Journal of retail \& Distribution Management.

Esfahani, Arash. Roudbari, Sohail. (2012). Entrepreneurial marketing processes and increase market share. National Conference on entrepreneurship and business management knowledge.

Esfandiari, Abolfazl. Taj Puri, Ghorban. Pakzad, Ali Reza. (2010). the factors affecting the production of export of Turkmen Carpet. Journal - Research Association of Iranian carpets. Issue 17, autumn.

Farhangi, Ali Akbar. (2008). Sales company and provide a mathematical model to assess the effects on profitability. Journal of Marketing Management, No. 6.

Noak, Smith. (2010). "The network paradigm and marketing organization: Developing management agenda", European Journal of Marketing.

Webster \& et al. (2005). "The Decline and Dispersion of Marketing Competence" MIT Sion Management Review. 